\title{
A TEORIA DOS DIREITOS FUNDAMENTAIS DE ROBERT ALEXY COMO MODELO ANALÍTICO DO DIREITO SOCIAL À MORADIA: ARGUMENTOS DE PRINCÍPIO NO CAMPO DE REFERÊNCIA DE SUA APLICABILIDADE IMEDIATA
}

\author{
ROBERT ALEXY'S FUNDAMENTAL RIGHTS THEORY AS AN ANALYTICAL MODEL \\ OF SOCIAL HOUSING RIGHT: PRINCIPLE ARGUMENTS IN A REFERENCE FIELD \\ OF IT'S IMMEDIATE APPLICABILITY
}

\author{
Miracy Barbosa de Sousa Gustin ${ }^{1}$ \\ Regina Lúcia Gonçalves Tavares ${ }^{2}$
}

\section{RESUMO}

O direito à moradia, situado como direito social fundamental, é aqui analisado sob um modelo analítico que permite sua classificação como um direito fundamental completo, essencialmente exigente tanto de ações positivas quanto negativas por parte do Estado, percepção teórica que então permite com que seu marco normativo constitucional seja pensado como dispositivo de aplicabilidade imediata e não sujeita à reserva do possível. Optou-se por uma análise teórica pela qual o correspondente normativo do direito social à moradia é estudado sob uma ótica principiológica que, partindo de Ronald Dworkin (2010; 2013), encontra em Robert Alexy (2014; 2015) sua grande justificativa teórica. O problema que se coloca neste trabalho é: a teoria dos direitos fundamentais de Alexy possibilita a construção de um modelo analítico do direito à moradia como um direito fundamental social de aplicabilidade imediata, porquanto capaz de referenciar teoricamente e de maneira robusta a jurisprudência que se aplica a este tipo de demanda? Os resultados permitiram encontrar um pujante sistema de pensamento segundo o qual o direito à moradia, como um direito fundamental completo, requer a necessidade do reconhecimento da plenitude de sua indiscutível aplicabilidade frente às questões apresentadas em demandas fundiárias nos quais ele é questionado.

Palavras-chave: Direitos fundamentais. Direito à moradia. Direito fundamental completo. Aplicabilidade imediata. Jurisprudência.

\footnotetext{
ABSTRACT

The right to housing, situated as a fundamental social right, is analyzed under an analytical model that allows its classification as a complete fundamental right, essentially demanding both positive and negative actions by the State, is a theoretical perception that allows its landmark constitutional

${ }^{1}$ Mestrado em Ciência Política pela Universidade Federal de Minas Gerais e doutorado em Filosofia do Direito pela Universidade Federal de Minas Gerais. Pós-Doutora em Metodologia do Ensino e da Pesquisa pela Universidade de Barcelona/CAPES. Professora associada aposentada da Universidade Federal de Minas Gerais. Professora do Corpo Permanente do Programa de Pós-Graduação em Direito da UFMG. Afiliação:Universidade Federal de Minas Gerais (UFMG). Lattes: http://lattes.cnpq.br/5797844664777595

ORCID: https://orcid.org/0000-0002-2770-5516. E-mail: miracygustin@gmail.com

${ }^{2}$ Doutoranda em Direito pela Universidade Federal de Minas Gerais (UFMG). Mestre em Direito e Instituições do Sistema de Justiça pela Universidade Federal do Maranhão (PPGDir-UFMA). Possui graduação em Direito pela Universidade Ceuma (1999). Especialista em Processo Civil pela PUC/Campinas (2002). Especialista em Processo Civil pela Universidade Ceuma (2004). Atualmente é professora da Universidade Federal de Juiz de Fora (UFJF).Afiliação:Universidade Federal de Minas Gerais (UFMG). Lattes:http://lattes.cnpq.br/3828705402274385 ORCID:https://orcid.org/0000-0003-2524-5103. E-mail:rlg.t@ hotmail.com
} 
normative is thought of as a device of immediate applicability and not subject to the reserving of the possible. We opted for a theoretical analysis whereby the normative correspondent of the social right to housing is studied from a principles perspective that, starting from Ronald Dworkin (2010; 2013), finds in Robert Alexy $(2014 ; 2015)$ his great theoretical justification. The problem that arises in this work is: Alexy's theory of fundamental rights makes it possible to build an analytical model of the right to housing as a social fundamental right by immediate applicability, capable of theoretically and robustly referring to the jurisprudence that applies to this type of demand? The results made it possible to find a powerful system of thought according to which the right to housing, as a complete fundamental right, requires the recognition of the fullness of its indisputable applicability to the issues presented in housing claims in which it is questioned.

Keywords: Fundamental rights. Right to housing. Complete fundamental right. Immediate applicability. Jurisprudence.

\section{INTRODUÇÃO}

Em corriqueira pesquisa jurisprudencial na qual adotado como descritor de busca o direito à moradia, este contextualizado como um problema jurídico recorrente nas mais diversas modalidades de litígios fundiários que marcam a realidade social brasileira, profundamente afetada pelo crescente déficit habitacional e pela recorrência das mais diversas formas de habitação precária, é comum nos depararmos com resultados bastante díspares quando posta em questão a sua exigibilidade.

Essa disparidade se materializa na forma contraditória com que o alcance do direito à moradia é tratado pela jurisprudência brasileira. Em demandas nas quais o tratamento deste direito assume centralidade - seja em remoções ou despejos forçados de pessoas residentes em áreas de risco, seja em ações de reintegração de posse, ambas cumuladas ou não com pedidos de demolição - o posicionamento dos julgadores transita entre dois polos distintos: de um lado, os que reconhecem determinados limites à intervenção jurisdicional no contexto das ações do Poder Público e, por esta razão, identificam o direito social à moradia como um direito social sujeito à reserva do possível, ou seja, aos limites orçamentários do Estado; de outro lado, diversos outros julgados reconhecem a eficácia plena do artigo $6^{\circ}$ da Constituição Federal, o que asseguraria ser o direito à moradia um direito de fundamentalidade indiscutível, a ser oposto contra o Estado, pelo que devendo este último sucumbir à sua aplicabilidade imediata.

É o que ilustram os exemplos abaixo colacionados:

Em verdade, é fato incontestável que o Apelante teve consideráveis prejuízos de ordem moral e material com o rompimento da barragem de água e, consequentemente, a inundação de seu imóvel. Contudo, tal como estabelecido pelo ilustre magistrado na sentença ora recorrida, afigura-se irrazoável e desproporcional exigir da Municipalidade providências com relação a todas as famílias que fixam residência em áreas de risco inadequadas para habitação, 
principalmente porque estas colocam-se, voluntariamente, em tal situação ao optar por fixar residência em áreas de ocupação irregular. (BRASIL. Tribunal de Justiça do Amazonas. Apelação Cível julgada em 15 de setembro de 2020)

Sendo assim, tem-se que, diante do conjunto probatório carreado aos autos, em especial ainda pelas fotografias (fls. 58/60), forçosa é a manutenção da decisão de protege a família lá residente, determinando a sua remoção imediata para local seguro. Outrossim, totalmente descabido se aventar no caso o princípio da reserva do possível, mormente quando se tem de um lado o direito fundamental de uma família em situação de risco de vida. Não se legitima a invocação da reserva do possível diante de uma omissão dos deveres estatais de prestação constitucionalidade impostos ao Poder Público. Por fim, vale ressaltar que, quanto ao direito social à moradia, dispõe a Constituição Federal em seu art. 23, inciso IX, que também é competência comum da União, dos Estados, do Distrito Federal e dos Municípios a promoção de programas de construção de moradias e a melhoria das condições habitacionais e de saneamento básico e, em relação ao Município, estabelece o art. 30, inciso VIII, que compete a ele promover, no que couber, adequado ordenamento territorial, mediante planejamento e controle do uso, do parcelamento e da ocupação do solo urbano, o que foi salientado na douta decisão. (BRASIL. Tribunal de Justiça do Rio Grande do Sul. Agravo de Instrumento julgado em 02 de outubro de 2019)

$\mathrm{O}$ direito à moradia foi formalmente inserido no rol dos direitos sociais da Constituição Federal de 1988 (art. 6º), pela Emenda Constitucional 26, de 14 de fevereiro de 2000. Trata-se de ramo cuja complexidade se externa em diferentes áreas do direito público, sobretudo nas grandes áreas do direito constitucional e do direito administrativo. É indivisível, interdependente e está intimamente ligado a um conjunto de outros direitos da personalidade conexos a este direito, por exemplo, o direito à vida, direito à saúde, o direito à intimidade, direito à propriedade, direito ao sossego, direito à liberdade. A correção de políticas públicas pelo Poder Judiciário deve se dar em situações excepcionais (cf. STF, ARE 761127 AgR/AP, Rel. Min. Roberto Barroso, Primeira Turma j. 24/6/2014). A jurisprudência adota posição restritiva para imposição de sentenças de mérito que obriguem o Estado a adotar/alterar políticas públicas. (BRASIL. Tribunal de Justiça de São Paulo. Apelação Cível julgada em 11 de junho de 2020)

De fato, a confusão acerca da natureza e alcance do direito à moradia, enquanto garantia constitucional que pode ou não ser exigida judicialmente em face do Estado, referencia um tipo de incongruência que atinge a construção jurisprudencial dos direitos sociais como um todo, sendo capaz de produzir certo estado de insegurança jurídica quanto à definição dos limites de abrangência das garantias previstas no artigo $6^{\circ}$ da Constituição Federal, sobretudo quando localizada nas instâncias de base, mais próximas às origens de diversos litígios de natureza fundiária e, portanto, potencialmente, mais aptas a impactarem diretamente as condições materiais de vida das pessoas envolvidas.

Trata-se de um tipo de divergência capaz de ferir a integridade da interpretação deste relevante dispositivo constitucional, sobretudo porque, além de gerar colidentes precedentes no contexto das discussões acerca da imediatidade do direito acenado, esvazia o debate jurídico do real contexto de desigualdade social que afeta estruturalmente o acesso à moradia digna no país, o que justifica então a importância de se analisar em termos principiológicos o conteúdo desta norma, 
prescrita em forma de garantia, emergida historicamente enquanto dispositivo de estatura constitucional.

De um lado a jurisprudência permanece ciosa das limitações econômico-financeiras do Poder Público e da limitação de sua competência constitucional e, por esta razão, recolhe a mão quando é instada a decidir determinadas causas onde a realização prática do direito social à moradia é reclamada por parte de um contingente populacional alijado dos processos formais de aquisição da casa-própria e, por conseguinte, é enredado em ações judiciais nas quais é alvo de remoções e despejos forçados.

De outro, ao priorizar as funções econômicas do Estado, em detrimento da realização imediata deste direito social, finda por fazer uma opção valorativa que, grosso modo, desarticula o objetivo fundamental da República Federativa do Brasil, este textualmente consistente na erradicação da pobreza e da marginalização e na redução das desigualdades sociais e regionais, portanto sujeitando este escopo prioritário, enraizado no princípio da dignidade da pessoa humana, a um outro éthos, este mais adequado a dispositivos de natureza econômica e orçamentária.

Assim, a realidade empírica que noticia este impasse na jurisprudência brasileira é sugestiva de um tipo de pesquisa teórica cujo objetivo será o de analisar a fundamentalidade do direito à moradia desde um modelo analítico que permita a sua classificação como um direito fundamental completo, qual seja aquele que demanda tanto ações positivas quanto ações negativas por parte do Estado, ou seja, que condicione o Estado brasileiro tanto a praticar atos que o viabilizem, quanto a se abster de ações que impeçam a sua factual efetivação.

Tal percepção nasce de uma atividade conjunta de pesquisa empírica atualmente empreendida em forma de pesquisa jurisprudencial realizada no âmbito do Doutorado, em curso junto ao Programa de Pós-Graduação em Direito da Universidade Federal de Minas Gerais, cujo objetivo lá empreendido é o de realizar um apanhado sobre a produção jurisprudencial relativa à temática das remoções forçadas motivadas pelo risco. Embora o objetivo deste artigo não seja o de articular os resultados quantitativos desta pesquisa jurisprudencial, os achados com que nos deparamos no contexto da realidade empírica investigada, ofereceram-nos um fecundo campo secundário de análise, por meio do qual, dada a recorrência de formas díspares de compreensão acerca do alcance e da exequibilidade prática do direito fundamental à moradia, justificou-se, paralelamente, o presente estudo teórico que ora se presta a investigar a essência de sua fundamentalidade, o que é objeto deste artigo.

O arsenal teórico capaz de permitir com que o marco normativo constitucional presente no artigo $6^{\circ}$ da Constituição Federal seja analisado sob a defesa de sua fundamentalidade, será aquele que permite analisar o direito social à moradia sob uma ótica principiológica que, partindo 
de Ronald Dworkin (2010; 2013), encontra em Robert Alexy (2015; 2015b) sua grande justificativa teórica.

Considerando o que preceituam Dworkin e Alexy acerca dos direitos fundamentais, dando especial enfoque àqueles que o último chama de direitos à prestação em sentido estrito ${ }^{3}$ - ou direitos sociais fundamentais -, busca-se enfatizar os valores constitucionais que estruturam o caráter social do direito à moradia, como aspecto de uma política urbana alinhada ao projeto democrático que identifica o éthos estruturante da sociedade brasileira como aquele a partir do qual compromete-se ela a erradicar a pobreza e a marginalização de sua gente, bem como a reduzir as desigualdades sociais e regionais.

Por esta razão, ao se utilizar, a título de pressupostos conceituais que irão orientar a presente investigação, a ótica principiológica acudida pelo pensamento de Robert Alexy (2015; 2015b) para entender a estrutura normativa do direito à moradia, busca-se atingir o objetivo específico de aqui oferecer um modelo analítico do direito fundamental à moradia capaz ao seu turno de lanças luzes sobre a produção jurisprudencial acerca desta difícil temática.

O problema que se coloca neste trabalho é: a teoria dos direitos fundamentais de Alexy possibilita a construção de um modelo analítico do direito à moradia como um direito fundamental social completo, porquanto de aplicabilidade imediata, capaz de referenciar teoricamente e de maneira robusta a jurisprudência no que tange à vinculação de tomadas de ações positivas e negativas por parte do Estado? Os resultados permitiram encontrar um pujante sistema de pensamento segundo o qual o direito à moradia, como um direito fundamental completo, requer a necessidade do reconhecimento da plenitude de sua indiscutível aplicabilidade frente às questões apresentadas em demandas fundiárias, nas quais sua exequibilidade é questionada.

\section{DIREITO À MORADIA E DÉFICIT HABITACIONAL}

Segundo dados da pesquisa realizada pela Fundação Getúlio Vargas (FGV) em 2017, o déficit habitacional no Brasil seria de 7,78 milhões de moradias faltantes, isto num cenário de projeções que aponta para um número que crescerá para 11,9 milhões até 2027 (FGV, 2018). Também assinalou aquela pesquisa que, das famílias que integram esse cenário deficitário, 91,7\% delas estariam enquadradas numa faixa de renda que vai até 3 salários mínimos e que, para se atender as necessidades habitacionais desse grupo específico, seria necessário um investimento em torno de R \$ 104,8 bilhões para a construção de 7,1 milhões de novas unidades.

\footnotetext{
3 “Direitos à prestação em sentido estrito são direitos do indivíduo, em face do Estado, a algo que o indivíduo, se dispusesse de meios financeiros suficientes e se houvesse uma oferta suficiente no mercado, poderia também obter de particulares.” (ALEXY, 2015, p. 499).
} 
A Fundação João Pinheiro apresentou em 2018 (FJP, 2018) o resultado de sua pesquisa sobre o déficit habitacional de 2016, este em torno de 6,3 milhões moradias faltantes ${ }^{4}$. Naquela ocasião, a pesquisa também acusou que, no que diz respeito aos componentes e subcomponentes que integram sua metodologia de contabilidade dos domicílios inadequados (ônus excessivo com aluguel, coabitação familiar, habitações precárias e adensamento excessivo dos domicílios alugados), cerca de metade dessa carência era apresentada por famílias cuja renda não ultrapassaria os três salários mínimos mensais.

Aponta ainda a Fundação João Pinheiro que $87,7 \%$ do total do déficit habitacional do Brasil está representado pela falta de moradia na área urbana, sendo também na área urbana onde se concentram cerca 6,3 milhões de imóveis vazios ou subutilizados (FJP, 2018). Já o IBGE (Instituto Brasileiro de Geografia e Estatística) noticia a presença de 8,27 milhões de brasileiros, ocupando em média 2,47 milhões de domicílios localizados em 27.660 áreas de risco em todo o país (IBGE, 2018, p. 32).

O conceito de déficit habitacional, ainda que compatível com uma memória discursiva que pensa o problema da falta de habitação e seu enfrentamento pela via da reposição de estoque de unidades e pela promoção da transferência da propriedade privada via casa-própria, tem sido, todavia, a anatomia de um discurso pelo qual se faz possível hoje no país, dialogar com a questão da falta ou da precariedade da moradia. Longe de se mostrar um dado estatístico isolado, constitui um importante indicador material a partir do qual as demandas fundiárias devem ser pensadas.

Embora seja uma noção cujas escolhas temáticas possuem dependência histórica com o discurso de que o problema da falta de moradia se resolve pela via da lógica de produção de mais casas, limitando-se à superfície de emergência de uma política habitacional historicamente condicionada ao valor de troca, dependente de que o mercado produza e venda imóveis via subsídio governamental, isto sem levar em conta outras soluções habitacionais embasadas em sistemas comunitários de regularização e autogestão, trata-se de um tipo específico de produção de dados que em muito pode auxiliar na investigação da capacidade dessa mesma política habitacional em

\footnotetext{
${ }^{4}$ A divergência numérica evidenciada em relação às pesquisas da FGV e da FJP, se devem ao fato de que a pesquisa feita pela Fundação Getúlio Vargas, contratada pela Associação Brasileira de Incorporadoras Imobiliárias ABRAINC e apresentada em outubro de 2017, embora realizada com base nos indicadores habitacionais formulados pela Fundação João Pinheiro e adotada como referência pelo Governo Federal (ônus excessivo com aluguel, coabitação familiar, habitações precárias e adensamento excessivo dos domicílios alugados), sofreu ajustes metodológicos, com vistas a reconstruir alguns de seus componentes. Por esta razão, os números apresentados levaram em conta a incorporação da "coabitação total" - no qual se considerou o número total de famílias coabitantes, relacionando-as com o número de domicílios existentes - e do número de domicílio improvisados, em compatibilidade com a projeção da população brasileira total do IBGE para o ano de 2017, o que representou um aumento no resultado final do déficit. Todavia, ainda que com a aplicação destas alterações metodológicas, com exceção dos números representativos da coabitação familiar, em relação aos demais ítens a divergência não é tão acentuada assim. Vejamos: Habitação precária 12,4\% FGV/2017 - 14,8\% FJP/2016; coabitação familiar 41,3\% FGV/2017 - 29,9\% FJP/2016; ônus excessivo com aluguel 42,3\% FGV/2017 - 50,0\% FJP/2016; adensamento excessivo 3,9\% FGV/2017 - 5,2\% FJP/2016. (FGV, 2018, p. 9-10; FJP, 2018).
} 
oferecer um enfrentamento à altura da realidade desigual segundo a qual, um contingente alijado desses processos de compra da casa própria, segue desafiando o Estado, no sentido de revelar sua incapacidade em promover a materialização deste direito de inegável importância social.

A julgar pelos números deficitários que se apresentam de forma crescente no panorama da rápida urbanização do país ${ }^{5}$, vê-se que a dinâmica deste paradigma de produção de moradia segue se construindo com base em um forte processo de disputa pela ocupação adequada do solo ${ }^{6}$. O resultado disto é a crescente submissão do lado mais frágil desta contenda a processos de exclusão socioespacial e, portanto, a produção retroalimentada de mais precariedade, já que fruto de uma dinâmica social segundo a qual as populações empobrecidas, afastadas dos processos de aquisição de moradia via compra e venda da casa própria, vão sendo empurradas a autoproduzir seus próprios territórios e moradias, estes muitas vezes edificados em terrenos alheios ou mesmo impróprios para a habitação.

Paradoxalmente, é mais ou menos desde 1950, ou seja, desde o momento histórico no qual acontece a intensificação do processo de urbanização do país, que as relações de poder, estruturantes do tipo de organização política e social existentes no Brasil, vêm tentando articular, inclusive juridicamente, dispositivos de segurança e controle ${ }^{7}$ tendentes a lidar com algo que parece se tornar cronicamente problemático em nossa conjuntura social: a emergência habitacional. Inobstante o que se construiu durante todas essas décadas, de 1960 a 2020, nas várias versões pelas quais se buscou articular uma política habitacional no país, é a crise da moradia o fato social e político que, no campo da habitação popular, assume constância na realidade urbana brasileira e invariavelmente, segue desafiando a jurisprudência quanto ao real alcance do direito social à moradia.

$\mathrm{O}$ enfrentamento político desta crise tem sido historicamente pensado desde um modelo segundo o qual a produção de moradia deixa cada vez mais de ser uma política social estatal, para se tornar uma reserva de capital materializada na prática estatal de mercantilização e depois de

\footnotetext{
${ }^{5}$ Segundo dados da Divisão de População do Departamento de Assuntos Econômicos e Sociais das Nações Unidas, em termos projecionais, a população urbana no Brasil cresceu de 36,2\%, em 1950, para 87,1\%, em 2020 (ONU, 2018).

${ }^{6}$ É possível se pensar nas condições de possibilidade dessa disputa desde o momento de sua irrupção histórica quando, no Brasil, a abolição do regime formal de escravização do povo negro fez surgir a necessidade de introdução de um regime de proteção jurídica à propriedade privada. A Lei de Terras, de 1850, abolindo no país o antigo regime de doação ou concessão de terras pela coroa, passa a priorizar a titulação em detrimento da mera ocupação, possibilitando a oposição do domínio da terra pelo colonizador em face do ex-escravizado, doravante tornado pobre e desterrado. A propriedade privada passa então a ser assegurada como um direito juridicamente protegido e oponível às ocupações.

${ }^{7}$ A pertinência dessa afirmação encontra lastro teórico na compreensão que Michel Foucault desenvolve sobre as relações de poder, segundo a noção de biopolítica que ele vai desenvolver nas obras: História da sexualidade I: a vontade de saber (1999); Em defesa da sociedade (2005); Segurança, território e população (2008); e $O$ nascimento da biopolítica (2008b), obras que ajudam a pensar como a vida vai se sujeitando aos mecanismos da política e do Estado: mecanismos jurídicos de uma política sobre um povo e seu território; mecanismos disciplinares de uma política sobre o corpo, pela individualização de uma multiplicidade; mecanismos de segurança de um política de regulação sobre uma massa populacional (FOUCAULT, 2008, p. 16).
} 
financeirização daquele direito, cada vez mais tomado como um produto alimentado pelas parcelas mensais dos contratos de financiamento, com forte tendência a adentrar, sem perspectiva de volta, nas engrenagens do mercado.

A política habitacional brasileira, ao longo das últimas seis décadas, tem caminhado, invariavelmente, pari passu, com esta metodologia de ação política segundo a qual o mercado passa a ocupar um lugar privilegiado enquanto agente garantidor das condições básicas de bem-estar a serem atingidas pela via do consumo. Por outro lado, e a grosso modo, é possível notar que esse sistema de ideias tem codificado de forma crescente a interpretação judicial do direito social à moradia, sendo parte contígua e não oposta desta performance de poder. Evidencia uma racionalidade pela qual farta jurisprudência segue filtrando conflitos fundiários submetidos à sua apreciação, frequentemente pela lógica das funções econômicas do Estado, porquanto buscando guarida no apregoado princípio da reserva do possível.

$\mathrm{Na}$ arqueologia dos discursos no qual o princípio da reserva do possível é acionado para justificar os processos de deslocamento forçados levados a efeito sem o oferecimento de soluções habitacionais postas em favor da população atingida, o sentido que sobressai desta via de solução, comum na jurisprudência, aponta certa fidelidade às noções securitárias ${ }^{8}$ (FOUCAULT, 2008, p. 15) que atuam em prol das funções econômicas do Estado como um bem jurídico em si, mesmo que em detrimento de direitos sociais legislados.

De fato, no cenário destas formas precárias de ocupação do solo pode-se perceber a inscrição de práticas jurídicas ativas no sentido de manutenção desta ordem securitária da troca contratual, tendentes a servirem de pontos de apoio às relações de poder que institucionalizam as formas hegemônicas de acesso à moradia via aquisição privada da propriedade do solo, porquanto, em consonância com a rotinização desta política privatística do Estado. Levam a efeito processos massivos de despejos e remoções forçadas sem o oferecimento de uma alternativa habitacional às pessoas removidas e despejadas, e mobilizam-na quase sempre sob justificativas segundo as quais o Judiciário não pode invadir a competência orçamentária do Estado.

O modo de funcionamento das remoções e reintegrações de posse, operacionalizadas sem solução de continuidade habitacional em relação aos seus alvos, findam por reatualizarem a questão do déficit habitacional no país; estabelecem com ele uma espécie de construção conjunta da qual sobressai uma conexão direta e indissociável - ou mesmo se apresenta como um efeito colateral -

\footnotetext{
${ }^{8}$ Depois da soberania e da disciplina, a técnica que Foucault vai reconhecer e que se sobressai nesse processo de transformação dos modos de gestão capitalista do Estado, é a segurança: "A segurança é uma certa maneira de acrescentar, de fazer funcionar, além dos mecanismos propriamente de segurança, as velhas estruturas da lei e da disciplina" (FOUCAULT, 2008, p. 14). As características gerais desse dispositivo seriam: a conformação de espaços de segurança por uma série indefinida de elementos; o tratamento aleatório desses elementos e das probabilidades que os constituem; a normalização de condutas; a repartição espacial de multiplicidades e a circulação, em prol das diferentes funções econômicas do Estado (FOUCAULT, 2008, p. 15).
} 
do modelo de política habitacional historicamente adotado no país, reproduzindo as formas de gestão governamental securitárias que se inscrevem neste campo, porquanto merecendo serem confrontados com a forma como o Direito se organiza e reorganiza dentro dessas dinâmicas excludentes.

\section{O DIREITO À MORADIA E A CONSTITUIÇÃO FEDERAL}

Previstos no capítulo II da Constituição Federal, os direitos sociais se acham, ainda que de forma não concentrada ${ }^{9}$, elencados no artigo $6^{\circ}$ da $\mathrm{CF}$, onde lá se pode identificar a presença do direito à moradia.

A moradia digna já havia sido erigida à categoria de um direito humano - porque não dissociável da dignidade da pessoa humana - pela Declaração Universal dos Direitos do Homem, de $1948^{10}$ e pelo Pacto Internacional sobre Direitos Econômicos, Sociais e Culturais (PIDESC/ONU), adotado pela XXI Sessão da Assembleia Geral das Nações Unidas, em 19 de dezembro de 1966, e posteriormente albergado pela legislação nacional, por meio do Decreto n $^{\circ} 591$, de 6 de julho de 1992.

Muito embora tenha sido reconhecido naqueles marcos normativos internacionais, o direito à moradia somente passou a integrar de forma explícita o texto constitucional brasileiro por força da Emenda Constitucional n ${ }^{\circ}$ 26, de 14 de fevereiro de 2000, a partir da qual foi implantado como um direito social no artigo $6^{\circ}$ da Constituição Federal de 1988.

Ausente originariamente do rol dos direitos sociais previstos no artigo $6^{\circ}$, a lacuna concernente ao direito à moradia como um direito social constitucional revelava um descompasso no desenho da própria Constituição Federal, vista a partir do contexto de sua promulgação, no ano de 1988.

\footnotetext{
9 "Nesse sentido, à semelhança dos demais direitos fundamentais, os direitos sociais não se resumem ao elenco do artigo $6^{\circ}$ da CF, abrangendo também, nos termos do artigo $5^{\circ}, \S 2^{\circ}$, da CF, direitos e garantias implícitos, direitos positivados em outras partes do texto constitucional (fora do Título II) e ainda de direitos positivados em tratados internacionais. Registre-se que a jurisprudência do Supremo Tribunal Federal, alterando o entendimento até a pouco vigente, atualmente tende no sentido de consagrar a hierarquia supralegal, mas ainda infraconstitucional, dos tratados em matéria de direitos humanos, isto é, a prevalência do tratado sobre direito infraconstitucional interno (RE 466.343/SP), mantida, todavia, a atribuição de hierarquia meramente legal aos tratados sobre outras matérias. Diversamente, verifica-se uma posição menos conservadora quanto ao reconhecimento dos direitos implícitos e dispersos pelo texto constitucional, como são exemplos entre outros, o direito à moradia (hoje inserido no texto original da CF) [...]”. (SARLET, 2014, p. 540-541)

${ }^{10}$ Artigo XXV 1. Todo ser humano tem direito a um padrão de vida capaz de assegurar-lhe, e a sua família, saúde e bem-estar, inclusive alimentação, vestuário, habitação, cuidados médicos e os serviços sociais indispensáveis, e direito à segurança em caso de desemprego, doença, invalidez, viuvez, velhice ou outros casos de perda dos meios de subsistência em circunstâncias fora de seu controle. (Organização das Nações Unidas. Declaração Universal dos Direitos do Homem, 1948).
} 
O fato é que a aprovação do direito à moradia, como norma constitucional declarada, se deu somente 12 anos após a edição da Carta Magna, na qual, desde sua origem, já consignava, no artigo $5^{\circ}$, inciso XXIII, a função social da propriedade, e no artigo 182, a previsão de políticas de desenvolvimento urbano para a promoção das funções sociais da cidade ${ }^{11}$, o que soava um tanto quanto contraditório, já que as funções sociais da propriedade e da cidade não poderiam ser pensadas, jurídica e politicamente, prescindindo de sua premissa maior, qual seja a questão social da habitação, no caso a relacionada à moradia digna a ser pensada como um direito inequívoco em prol do qual o Estado deveria atuar.

Todavia, como dito, atendendo o Brasil à regulação dos instrumentos internacionais concernentes à moradia e, ademais, cedendo a pressões internas dos movimentos populares e demais entidades $^{12}$, tal antinomia presente na norma constitucional foi corrigida pela referida emenda constitucional, que findou por inserir no texto do artigo $6^{\circ} \mathrm{o}$ direito à moradia como direito social.

No campo jurídico-normativo, o desenho institucional da Constituição Federal de 1988 demarcou o direito social à moradia como um direito cujo alcance prático referenciaria o desenvolvimento de uma política urbana capaz de realizá-lo funcionalmente. Trata-se de um direito calçado em uma lógica publicista, porquanto definida numa dimensão funcional, cujo conteúdo se acha representado pelas funções sociais da propriedade e da cidade.

De fato, o direito à moradia, como um direito social, não se dissociou dos dispositivos constitucionais que em essência se dedicam à Política Urbana, especialmente no que tangenciam os artigos $5^{\circ}$, inciso XXII e 182 e correspondentes parágrafos e incisos, da Constituição Federal - e que apresentam como ponto de destaque o aspecto funcional que dá sentido ao direito à propriedade como um direito cujo exercício é condicionado à sua pertinência social, esta intrinsecamente ligada ao direito de que a vida urbana digna possa se realizar indistintamente a todas as pessoas que vivem e utilizam dos espaços da cidade.

\footnotetext{
11 "A noção de direito à cidade adquiriu forma com as proposições que foram resultado da formulação de uma Emenda Popular de Reforma Urbana por um conjunto de entidades e associações de classe, organizações não governamentais-ONGs, associações civis, movimentos e grupos sociais que atuam com a questão urbana que compreenderam a importância de participar do processo institucional da Assembleia Nacional Constituinte. A emenda popular subscrita por 131.000 eleitores foi apresentada pela Articulação Nacional do Solo Urbano ANSUR, Movimento de Defesa do Favelado - MDF, Federação Nacional dos Arquitetos - FNA, Federação Nacional dos Engenheiros - FNE, Coordenação Nacional dos Mutuários e Instituto dos Arquitetos do Brasil IAB. A emenda popular da Reforma Urbana teve um papel importante no processo constituinte, pois vários dos seus termos foram utilizados como referência para elaboração do Capítulo da Política Urbana da Constituição de 1988." (SAULE JÚNIOR, 1997, p. 25)

12 "As ideias preconizadas pelo Centrão sobre a questão urbana eram nitidamente de evitar a instituição de normas constitucionais auto-aplicáveis de modo a capacitar o Poder Público para implementar uma política urbana geradora de responsabilidades e obrigações para os agentes privados pela utilização e apropriação do espaço urbano." (SAULE JÚNIOR, 1997, p. 31)
} 


\subsection{Direito fundamental à moradia?}

A análise do direito à moradia como um direito social fundamental a ser aqui empreendida, parte do pressuposto sustentado pela doutrina de que este compõe o rol dos direitos fundamentais previstos na Constituição Federal de 1988 (SARLET, 2012, 2014; BARROSO, 2003; CANÇADO TRINDADE, 2004, apud ESCRIVÃO FILHO; SOUZA JÚNIOR, 2016).

Outrossim, também aos direitos sociais se aplica o disposto no artigo $5^{\circ}, \S 1^{\circ}$, da $\mathrm{CF}$, de tal sorte que, a exemplo das normas de direitos fundamentais, as normas consagradoras de direitos sociais possuem aplicabilidade direta e eficácia imediata, ainda que o alcance desta eficácia deve ser avaliado sempre no contexto de cada direito social e à luz de outros direitos e princípios. (SARLET, 2014, p. 541)

Este posicionamento doutrinário, conforme ora transcrito, é reafirmado por Ingo Sarlet (2012) em uma outra obra na qual observa, a partir da disposição topográfica dos direitos sociais, a exemplo do direito à moradia (após o preâmbulo e na sequência dos princípios fundamentais), sua condição de autêntico direito fundamental: "além de traduzir maior rigor lógico, na medida em que os direitos fundamentais constituem parâmetro hermenêutico e valores superiores de toda a ordem constitucional e jurídica" (SARLET, 2012, p. 66), concretizam o princípio da dignidade da pessoa humana.

Os direitos sociais, como aqueles que garantem o valor de igualdade, estão elencados, assim como os Direitos Individuais e Coletivos, dentro do Título II da Constituição Federal, razão pela qual podemos, hermeneuticamente e no compasso dos posicionamentos doutrinários outrora esposados, adequá-los ao gênero dos "Direitos e Garantias Fundamentais".

De outro lado, ratifique-se que a categorização jurídica dos direitos sociais recebe no Brasil distintas classificações. Para Tavares (2014, p. 701), seriam os direitos sociais, direitos de segunda dimensão, porque sua realização exigiria do Poder Público uma atuação legislativa secundária. Para Barroso (2003), os direitos sociais seriam representados por normas constitucionais definidoras de direitos e, no que tange ao direito à moradia, exigíveis do Estado (BARROSO, 2003, p. 96), este responsável pela implementação concreta do que a Constituição inscreve como garantia.

Sucede que, no contexto político do Brasil, tomando como marco legal o Pacto Constitucional de 1988, formulado a partir da necessidade de legitimação de uma nova perspectiva democrática de desenvolvimento, nele deu-se o esmiuçamento hierarquizado das regras fundantes de suas ordens jurídicas. Esta disposição de direitos em cascata findou por instalar uma categorização geracional presente em parte do entendimento doutrinário, cujos fundamentos buscou 
classificar os direitos e garantias presentes na Constituição Federal (TAVARES, 2014).

Entretanto, segundo Escrivão Filho e Sousa Júnior (2016), ambos citando Cançado Trindade, trata-se de um pensamento que "tem, ademais, fomentado a visão atomizada dos direitos humanos, com todas as suas distorções" (CANÇADO TRINDADE, 2004 apud ESCRIVÃO FILHO; SOUSA JÚNIOR, 2016, p. 38), o que colabora para que sejam justificados alguns obstáculos que se materializam a partir do que o autor toma por uma falsa hierarquia decantada pela doutrina.

A compreensão de linearidade evolutiva geracional dos direitos humanos se materializa na interpretação do conteúdo formal da Constituição Federal, o que deixa ver o tratamento institucional prioritário de determinado núcleo de direitos fundamentais individuais, em detrimento de direitos econômicos, sociais e culturais.

$\mathrm{O} \S 1^{\circ}$, do artigo $5^{\circ}$ da Constituição Federal afirma que "as normas definidoras dos direitos e garantias fundamentais tem aplicação imediata” (BRASIL, 1988), o que, para efeito desta análise, adota-se a compreensão de que esta norma é daquelas cuja natureza é dotada de plasticidade, isto porque, uma vez não definindo textualmente a localização tópica dos direitos por ela guarnecidos em sua literalidade, favorece o entendimento de que a mesma abrange o conjunto de direitos fundamentais que vão se constituindo nos capítulos seguintes, a exemplo do Capítulo II, que trata dos Direitos Sociais, onde lá se acha inserido o direito à moradia (nem sempre expresso na norma constitucional, como anteriormente já se viu).

\footnotetext{
Para nós, o princípio da aplicabilidade imediata das normas definidoras dos direitos fundamentais abrange todos os direitos fundamentais (até mesmo os não previstos no catálogo Título II) e os não previstos na própria Constituição, desde que, quanto a estes, ostentem a nota distintiva da fundamentalidade material (como os decorrentes dos tratados internacionais em que o Brasil for signatário). Isto se dá não só porque o art. $5^{\circ}, \S 1^{\circ}$ refere-se textualmente a direitos fundamentais - fazendo uso da fórmula genérica "direitos e garantias fundamentais" - sem discriminá-los, mas também por conta de uma interpretação sistemática e teleológica que venha a recair na análise da referida disposição. (CUNHA JÚNIOR, 2016, p. 554)
}

Para Escrivão Filho e Sousa Júnior (2016), a limitação da abrangência do $\S 1^{\circ}$, artigo $5^{\circ}$, da Constituição Federal, revelaria uma intenção política de consignar formalmente uma Carta de Direitos que, no sentido mais prático, findaria por ratificar a índole liberal do Estado que hegemonicamente se sobrepõe às garantias constitucionalmente consignadas: "Em um cenário de extrema concentração da propriedade, como é notório nos países do sul-global, não fica difícil compreender o serviço que prestam tais ideias dominantes" (ESCRIVÃO FILHO; SOUSA JÚNIOR, 2016, p. 40).

Já Chinchilla Herrera (2009), professor da Faculdade de Direito e Ciências Políticas, da Universidade da Antioquia, na Colômbia, concebendo que os direitos fundamentais não se 
restringem àqueles batizados pela semântica constitucional, adverte para a necessidade de uma teoria adequada dos direitos constitucionais, firmada numa metodologia de precedentes, no propósito de que os direitos fundamentais previstos na carta fundante tenham uma "identidade confiável" (CHINCHILLA HERRERA, 2009, p. 12).

Para o citado autor, quanto aos direitos sociais, nos quais inseridos o direito à moradia digna e a função social da propriedade - da qual decorre a própria função social da cidade - sua classificação dimensional atenderia a um propósito categorizante de direitos sociais como direitos de índole prestacional, contidos naqueles chamados direitos de "segunda geração", assim hierarquizados para blindar os direitos de "primeira geração".

Retomando a discussão acerca do aspecto dimensional dos direitos fundamentais, e sua compartimentação dada sob os parâmetros de realização, tomados a partir da tradição eurocêntrica, este modelo teórico, defendido por Herrera, por exemplo, e transplantado para a realidade da América Latina, revela-se, no ponto de vista de Escrivão Filho e Sousa Júnior (2016), inadequado à trajetória político-cultural dos países inseridos nesta realidade pós-colonial, isto devido à importância do fortalecimento dos direitos humanos a partir de uma perspectiva de indivisibilidade e integralidade (ESCRIVÃO FILHO; SOUSA JÚNIOR, 2016, p. 38).

A respeito de se pensar os direitos humanos a partir de uma perspectiva de conjunto e a importância de assim adequá-los à realidade concreta, convém transcrever o seguinte fragmento:

\begin{abstract}
Por isso se diz que os direitos humanos não estão disponíveis aos pedaços, não sendo passíveis de uma seleção em que se priorizam uns em detrimento de outros. Não podem ser fragmentados ou dissociados entre si, de tal modo que a violação de um direito humano impacta diretamente em diversos outros correlatos como um efeito dominó, ao passo em que, por outro lado, a efetivação de um direito fortalece a garantia e própria efetivação de uma série de outros direitos intrínsecos à sua realização. (ESCRIVÃO FILHO; SOUSA JÚNIOR, 2016, p. 41)
\end{abstract}

Jordi Borja, ainda que mais numa perspectiva econômico-financeira ${ }^{13}$, trabalha a noção de concepção dialética de cidade e cidadania, no sentido de que o desenvolvimento e a proteção dos direitos individuais estão imbricados na expressão e na construção de direitos coletivos: "centralidades, mobilidade e acessibilidade socializadas, zonas social e funcionalmente diversificadas, lugares com atributos significantes” (BORJA, 2003, p. 22, tradução nossa).

Quando a proteção dos direitos fundamentais, dada determinada conjuntura social, é uma emergência, o problema de classificá-lo, categorizá-lo ou até mesmo fundamentá-lo, torna-se secundário frente à urgência em sua materialização prática. Ou seja, trata-se de saber "qual é o modo

\footnotetext{
${ }^{13}$ Em "Pátria empresa e mercadoria: notas sobre a estratégia discursiva do planejamento estratégico urbano", Carlos Vainer analisa o planejamento estratégico urbano a partir de signos de competitividade pelo investimento do capital e mundialização da economia, defendido por autores como o urbanista espanhol Jordi Borja, e suas consequências deletérias para a América Latina (VAINER, 2013).
} 
mais seguro para garanti-los, para impedir que, apesar das solenes declarações, eles sejam continuamente violados" (BOBBIO, 2004, p. 45).

Sabe-se que o tremendo problema diante do qual estão hoje os países em desenvolvimento é o de se encontrarem em condições econômicas que, apesar dos programas ideais, não permitem desenvolver a proteção da maioria dos direitos sociais. (BOBBIO, 2004, p. 63)

Porquanto, é possível compreender que os direitos econômicos, sociais e culturais (dentre aqueles nos quais se acha inscrita a função social da cidade e da propriedade), destarte inseridos na Constituição brasileira, juntamente com os direitos civis e políticos, espraiam-se numa espécie de teia normativa que resulta de um processo de emancipação política da América Latina, e decorre, seminalmente, de sua trajetória histórica e das necessidades acumuladas ao longo dos séculos em que esteve, ao menos institucional e formalmente, sob o domínio das metrópoles europeias. Derivam, portanto, de uma reação às relações internacionais de dependência, por isto "fruto dos processos de luta que vem reivindicar a proteção e intervenção do Estado para que os direitos ao trabalho digno, à terra e moradia, à educação e saúde, sejam efetivamente realizados”, (ESCRIVÃO FILHO; SOUSA JÚNIOR, 2016, p. 39).

Portanto, uma vez delimitadas as noções teóricas que nos ajudam a definir o alcance de fundamentalidade do direito à moradia, resta-nos então a construção do modelo analítico que suporte a compreensão de sua aplicabilidade imediata, capaz de referenciar teoricamente e de maneira robusta a jurisprudência no que tange à vinculação de tomadas de ações positivas e negativas por parte do Estado, o que se fará com fundamento na teoria dos direitos fundamentais de Alexy.

\section{DIREITO À MORADIA COMO DIREITO FUNDAMENTAL COMPLETO DE APLICABILIDADE IMEDIATA SEGUNDO A ANALÍTICA DE ROBERT ALEXY}

Regras e princípios, normas inseridas na estrutura social, política, administrativa e econômica do país, materializadas a partir de um mesmo ato institucional, no qual foram catalogadas garantias fundamentais e direitos sociais e políticos, constituídos a partir do valor jurídico da dignidade da pessoa humana, fundamento do próprio Estado democrático de Direito, garantidor da igualdade e da justiça social, passam doravante a demandar um exercício interpretativo cada vez mais fundamental para o contexto de sua aplicabilidade jurídica e de sua força normativa. 
Pode-se dizer que a dignidade da pessoa humana, como um princípio estruturante da Constituição Federal (SARLET, 2015), consiste num postulado normativo ${ }^{14}$ (MARTINS, 2015) que serve como premissa epistemológica de compreensão de todo o sistema jurídico, sendo, no caso do Brasil, um princípio assumidamente positivado no artigo $1^{\circ}$, integrante do rol dos direitos fundamentais. Trata-se de um princípio (e valor) fundante "que, como tal, deve servir de norte ao intérprete, ao qual incumbe a missão de assegurar-lhe a necessária força normativa”. (SARLET, 2014, p. 124).

Para Ingo Sarlet (2015, p. 106), o princípio da dignidade da pessoa humana possui o que o autor chama de dupla natureza, ou seja, é tanto princípio, quanto regra, portanto passível de vários níveis de realização, na medida em que "cada ser humano é, em virtude de sua dignidade, merecedor de igual respeito e consideração" (SARLET, 2015, p. 118).

De fato, refletindo-se sobre a dignidade da pessoa humana e o ideal de uma vida digna e sua categorização como direito de toda a humanidade, este se realiza na plenitude dos direitos humanos fundamentais, seja qual for sua dimensão, o que toca, de modo indelével, a questão dos direitos sociais.

A dignidade da pessoa humana é considerada por Robert Alexy (2015) uma ideia-chave substantiva, ou referência material dos direitos fundamentais, intimamente ligada aos direitos humanos, cujo modelo de análise, sugerido na obra Teoria dos Direitos Fundamentais (ALEXY, 2015), ressalva a pertinência da elaboração de uma teoria estrutural dos direitos fundamentais ${ }^{15}$, com vistas a se chegar, por exemplo, a um modelo analítico de direito fundamental social que permita sua compreensão segundo uma estrutura lógica ${ }^{16}$.

Ronald Dworkin (2010) fornece as pistas necessárias para nos aprofundarmos quanto ao pensamento estrutural e analítico de Robert Alexy, quando reconhece que uma teoria do direito que se limite a regras seria uma teoria incompleta, de modo que, para aquele primeiro autor, liberalista de princípios, o reconhecimento da preexistência de direitos, tais como a liberdade e a igualdade, na condição de postulados normativos ou cláusulas gerais, fundantes de determinado sistema jurídico, legitimam o próprio liberalismo e categorizam o positivismo puro como uma estratégia de

\footnotetext{
14 "Incide em equívoco vislumbrar no sistema jurídico apenas normas jurídicas, regras e princípios. Há também um terceiro tipo de elementos: são axiomas normativos que independem de positivação, valem ainda que não estejam expressa ou implicitamente positivados." (MARTINS, 2015, p. 34)

15 "Enquanto parte integrante de uma teoria integrativa, uma teoria estrutural é, primeiramente, uma teoria analítica. Mas apenas primeiramente, e não totalmente analítica, porque investiga estruturas como a dos conceitos de direitos fundamentais, de suas influências no sistema jurídico e na fundamentação no âmbito dos direitos fundamentais com vistas às tarefas práticas de uma teoria integrativa. Seu principal material é a Jurisprudência do Tribunal Constitucional Federal" (ALEXY, 2015, p. 42-43)

${ }^{16}$ (1) Todas as pessoas possuem dignidade humana. (2) A dignidade humana confere a todos os seres humanos o direito a serem levados a sério como pessoas. (3) Todos os seres humanos têm o direito de serem levados a sério como pessoas. (ALEXY; SILVA, 2015b, p. 171)
} 
restrição antiliberal ${ }^{17}$ (DWORKIN, 2013).

Para Dworkin, essa constatação teórica é capaz de revelar um nível de subordinação da norma positivada a preceitos a ela anteriores. Uma subordinação que, para o autor, muitas vezes imperceptível, é conceitual e política: ou seja, sujeita a argumentos de princípios e argumentos de política (DWORKIN, 2010).

Porquanto, quando ocorre de a norma positivada, tomada como um ato performático do legislador (MARTINS, 2015), vir a contradizer um princípio - este categorizado por Alexy como a expressão de uma pretensão de correção inerente ao próprio Direito -, esta contradição resultaria no que Ricardo Marcondes Martins (2015) chama de falha técnica do legislador, ou contradição performativa dos postulados normativos.

Segundo esta visão então, os argumentos de princípio, além de balizadores da regra positivada, seriam então justificadores também de decisões judiciais e, para Dworkin, estariam situados num campo de referência, de "proposições que descrevem direitos" (DWORKIN, 2010, p. 141). Com este raciocínio, Dworkin refunda a importância dos princípios, tomando-os como marco referencial de justiça (DWORKIN, 2010), com função de estabelecer standards de equidade que impeçam, por exemplo, que diante de determinado caso que, eventualmente, não se enquadre em regras preexistentes - os chamados casos difíceis -, sua solução não fique à mercê de critérios meramente discricionários adotados pelo julgador (DWORKIN, 2013), mas que sejam guarnecidos de fundamentos principiológicos.

Esta categorização teórica de Dworkin serve aqui de base e justificativa para o raciocínio que se vai desenvolver com base na Teoria dos Direitos Fundamentais de Alexy (2015) que, distinguindo regras e princípios, define-os a ambos como projeções de normas que devem ser reunidas como espécies de um mesmo gênero: "Tanto regras quanto princípios são normas, porque ambos dizem o que deve ser." (ALEXY, 2015, p. 87).

Deste pressuposto surge que, muito embora regras e princípios advenham de um mesmo tronco genérico, como espécies normativas, ambos devem ser analisados segundo suas peculiaridades. Para Alexy, são os princípios mandados de otimização (ALEXY, 2015), ou seja, acenam um variado grau de satisfatividade, cuja incidência dependerá de circunstâncias externas e, ainda, das demais regras que transitam em seu entorno e que com eles interagem. As regras, à sua vez, são o que são, ou seja, possuem um caráter de determinismo, porquanto dotadas de um espaço mais estreito de ampliação ou redução de sua interpretação e aplicabilidade, precisam ser subsumidas e devidamente ajustadas às condições fáticas e jurídicas sobre as quais incidem

\footnotetext{
${ }^{17}$ Os juízes devem aplicar o direito criado por outras instituições; não devem criar um novo direito. Isso é o ideal, mas por diversas razões não pode ser plenamente concretizado na prática. [...] Portanto, os juízes devem às vezes criar um novo direito, seja essa criação dissimulada ou explícita. (DWORKIN, 2010, p. 128)
} 
(ALEXY, 2015, p. 91).

Os princípios "podem ser satisfeitos em graus variados e pelo fato de que a medida devida de sua satisfação não depende somente das possibilidades fáticas, mas também das possibilidades jurídicas" (ALEXY, 2015, p. 90), além de serem considerados razões para regras, os princípios “podem também ser razões para decisões concretas" (ALEXY, 2015, p. 107).

Ao tratar dos modelos de regras e princípios, Alexy analisa a importância destes últimos, quando alcançam relevância para decisões que tratem de direitos fundamentais. Tal proeminência é assim reconhecida tanto naqueles princípios relevantes para os direitos individuais fundamentais, quanto nos que se referem a direitos fundamentais coletivos (ALEXY, 2015), como os direitos sociais, por exemplo. Entretanto, para o autor, a importância destes comandos não se produz exclusivamente ante o caráter formal de fundamentalidade que ostentam, mas: "A indagação acerca da demonstração de sua relevância substancial na argumentação no âmbito dos direitos fundamentais permanece indispensável" (ALEXY, 2015, p. 137).

Assim, face ao quanto dito, tem-se que categorização do direito à moradia como um direito fundamental completo, segundo leciona Robert Alexy, parte de um raciocínio que, desde uma exposição analítica da teoria estrutural dos direitos fundamentais, vai adequá-lo a um modelo de sopesamento (ALEXY, 2015, p. 514) entre o mínimo existencial e a realidade financeira do Estado (ALEXY, 2015, b, p. 176). A primeira etapa deste raciocínio corresponde à identificação do que o autor chama de sistema de posições jurídicas fundamentais, este definido por uma base teórica tríplice, definida em três elementos: direitos a algo, liberdades e competências (ALEXY, 2015).

Seriam três posições que Alexy reconhece como estruturantes de sua analítica, cuja divisão em arranjos distintos permite com que, em conjunto, assumam todas as três alta relevância, tanto quando analisadas individualmente, quanto quando associadas para análise em conjunto. No caso do direito à moradia, sua essência, enquanto direito social que integra o mínimo existencial compatível com uma vida digna, registra-se como norma de direito fundamental que se compatibiliza inequivocamente como um direito a algo e com a liberdade de exercê-lo em nome da dignidade da existência humana.

\subsection{Direito a algo: direito a ações negativas e direito a ações positivas}

O que Alexy chama de direito a algo é, ontologicamente, base conformadora do reconhecimento da existência de três posições jurídicas fundamentais: numa ponta, o sujeito que postula, na outra o Estado, destinatário da exigência de implementação de determinados direitos que, finalmente, enchem de conteúdo esta relação triádica que se completa no próprio objeto então postulado como um direito a ser implementado: 
[...] um direito a algo pode ser compreendido como uma relação triádica, cujo primeiro elemento é o portador ou titular do direito (a), o segundo elemento é o destinatário do direito (b) e o terceiro elemento é objeto do direito (G). [...] $\mathrm{O}$ objeto de um direito a algo é sempre uma ação do destinatário. Isso decorre da sua estrutura como relação triádica entre um titular um destinatário e um objeto. Se o objeto não fosse uma ação do destinatário, então, não faria sentido incluir o destinatário na relação. (ALEXY, 2015, p. 194).

$\mathrm{O}$ autor se utiliza de uma fórmula geral que então operacionaliza para definir seu raciocínio - $a$ (exemplificado por uma pessoa física ou jurídica, portadora ou titular de um direito) tem, em face de $b$ (o Estado, ou mesmo um particular, destinatário daquele pleito), um direito a $G$ (o objeto da postulação, que pode ser uma ação positiva ou uma abstenção). $G$, o objeto, será invariavelmente uma $a c ̧ \tilde{a} o$ de $b$ em favor de $a$ (ALEXY, 2015, 194).

Valendo-nos desta expressão proposta por Alexy, faz-se possível aplicá-la pensando-a em termos de uma postulação situada no campo do direito à moradia digna como um direito a algo, “(...) Art. $6^{\circ}$ São direitos sociais [...], à moradia [...] na forma desta Constituição.” (BRASIL, 1988) - que embora definido de forma simplificada, porquanto nele aparentemente prescritas duas posições (o titular, sujeito de direito, e o objeto), tal referência textual, ainda que concisa, não escamoteia o papel de seu destinatário, no caso o Estado, nem tampouco o sentido de que ele precisa sucumbir a um feixe de posições nas quais destacam-se um direito a algo e a liberdade para exercêlo. A realização prática desta previsão constitucional, portanto, se desmembra em direito a ações negativas e direito a ações positivas por parte de seu destinatário:

[...] os direitos a ações negativas correspondem àquilo que comumente é chamado de "direitos de defesa". Já os direitos em face do Estado a uma ação positiva coincidem apenas parcialmente com aquilo que é chamado de "direito a prestações", como será demonstrado mais adiante. [...] Os direitos dos cidadãos, contra o Estado, as ações estatais negativas (direitos de defesa) podem ser divididos em três grupos. O primeiro grupo é composto por direitos a que o Estado não impeça ou não dificulte determinadas ações do titular do direito; o segundo grupo, de direitos a que o Estado não afete determinadas características ou situações do titular do direito; o terceiro grupo, de direitos a que o Estado não elimine determinadas posições jurídicas do titular do direito. (ALEXY, 2015, p. 195-196)

O grupo de direito a ações negativas, ou direitos de defesa do cidadão contra intervenções dos Poderes Públicos, são tomados por Alexy (2015, p. 43) como direitos pertencentes a um "status negativo em sentido amplo". Neste campo de abstenções, aquelas onde o Estado esteja condicionado a não eliminar determinadas posições jurídicas do titular do direito e cujo protótipo exemplar seria, para o autor, por exemplo, o não impedimento ou a não dificultação ${ }^{18}$ de acesso a

${ }^{18}$ Nas palavras do próprio Alexy, "o impedimento de uma ação de $a$ por parte de $b$ ocorre quando $b$ cria circunstâncias que tornam faticamente impossível para $a$ realizar a ação. [...] É possível se falar em dificultação 
direitos constitucionalmente garantidos (ALEXY, 2015, 196). Seria exatamente o não-embaraço à sua fruição

O fato da primazia da propriedade privada como forma historicamente hegemônica de acesso à moradia no Brasil, forma esta sustentada por políticas habitacionais que ao longo de décadas têm dificultado o acesso a esse direito em relação a um grande contingente de pobreza urbana $^{19}$, pode aqui ser tomado como um exemplo de circunstâncias embaraçosaas (ALEXY, 2015, 197) de que $a$ aja em face de $b$ e que transitam de maneira fluida entre a dificultação e o impedimento de ações por parte do destinatário $(b)$ das demandas por moradia propostas pelo titular do direito (a), ou seja, um exemplo do que Alexy vai nominar como o supraconceito do embaraço

Requisitos objetivos e também subjetivos que permeiam por exemplo os contratos de financiamento da casa própria, subsidiados pelo Governo Federal, a exemplo da adequação do adquirente a faixas de salário-mínimo e à comprovação de saúde financeira, tornam explícitos esses embaraços: recentemente, por exemplo, o Programa Casa Verde Amarela, lançado pelo Governo Federal em $2020^{20}$, retira de seu espectro de ação de uma política habitacional voltada às classes menos favorecidas, as pessoas que não possuem renda comprovada, portanto eliminando a posição jurídica abstrata deste contingente populacional de se tornarem proprietários e, consequentemente, da liberdade de acessarem o direito à moradia.

de uma ação de $a$ por parte de $b$, se $b$ cria circunstâncias que podem deter a ação da $a$. [...] À distinção entre os conceitos de impedimento e dificultação somam-se diferenciações no interior desses conceitos. Existem espécies muito distintas de impedimentos e de dificultações, e as dificultações podem ter intensidades muito diferentes. Este último fato é a razão porque os limites entre o impedir e o dificultar são fluidos, o que, no entanto, não constitui um argumento contra a distinção." (ALEXY, 2015, p. 196-197)

19 "Os pesquisadores periodizam três fases da provisão habitacional, mas que de fato se resumem a duas: uma inicial baseada no fornecimento da moradia pelas empresas (as vilas operárias), reduzindo as despesas arcadas diretamente pelos trabalhadores, mas debitando-as no seu salário; e uma fase posterior, na qual a aceleração do fluxo migratório e a formação de um excedente de mão-de-obra torna desnecessária a fixação do trabalhador à empresa, que passa a transferir a responsabilidade de provisão da moradia e serviços urbanos para o próprio trabalhador e para o Estado." (ARANTES, 2009, p. 116).

${ }^{20}$ Confessadamente um programa para aumentar o estoque habitacional do país, voltado ao estímulo e à modernização do setor da construção civil (BRASIL, 2020), o Programa Casa Verde e Amarela (PCVA) instituído pela Lei n. ${ }^{\circ}$ 14.118/21 (resultado da Medida Provisória n 996/2020) e submetido à coordenação do Ministério do Desenvolvimento Regional, destina-se ao financiamento habitacional com recursos do FGTS e do FAR, e apresenta como inovação uma discreta redução na taxa de juros, aplicados aos contratos de aquisição de imóveis, indexados pela TR - com taxas mais previsíveis e pouco oscilantes - e, doravante, também pelo IPCA - índice de correção flutuante, mais atrelado à inflação -, observando padrões de diferenças regionais de diminuição de $0,25 \%$ para o norte e nordeste (BRASIL, 2021; BRASIL 2021b). Semelhante ao PMCMV, o PCVA também tem sua interação com o público escalonada de acordo com a faixa de renda das pessoas contratantes. A faixa 1,5 (Grupo Urbano 1), na qual enquadradas famílias com renda bruta de até $\mathrm{R} \$ 2.000,00$ aplicam-se taxas de juros de até 4,75\% ao ano, com subsídios de até $\mathrm{R} \$ 47.500,00$; a faixa 2 (Grupu Urbano 2), destinada a famílias com renda bruta de até $\mathrm{R} \$ 4.000,00$ e subsídios que podem chegar até $\mathrm{R} \$ 29.000,00$ de acordo com padrões de renda e localização do imóvel; e a faixa 3 (Grupo Urbano 3), para famílias com renda bruta de até R \$ 7.000,00 (BRASIL, 2021b; CAIXA, 2021). 
A garantia constitucional do instituto jurídico da propriedade é subjetivada na medida em que existem direitos individuais a não-eliminação de posições abstratas que se relacionam à criação, ao desfazimento e às consequências jurídicas da posição de proprietário. (ALEXY, 2015, p. 200-201).

Já no caso do grupo de direitos a ações positivas, ou de direito a prestações estatais em sentido amplo, Alexy os coloca em contraposição aos direitos de defesa e que se fundamenta no direito a um mínimo existencial, cuja satisfação pode ocorrer tanto por meio de uma de uma forma jurídica (criação de normas, ações positivas normativas em sentido amplo), quanto por meio ação fática (ações positivas fáticas em sentido estrito) (ALEXY, 2015, 202).

Saber se em que medida se deve atribuir aos dispositivos de direitos fundamentais normas que garantam direitos a prestações em sentido amplo é uma das questões mais polêmicas da atual dogmática dos direitos fundamentais. Especialmente intensa é a discussão sobre os assim chamados direitos fundamentais sociais, como, por exemplo, direitos à assistência social, ao trabalho, à moradia e à educação. (ALEXY, 2015, p. 433-434)

Para Alexy (2015), as diversas constituições de distintos países encontram como principal ponto de apoio dos direitos subjetivos a prestações do Estado o próprio direito à proteção da dignidade da pessoa humana, este compreendido como um enunciado geral sobre o qual se abrigam as demais normas garantidoras de direitos desta espécie, independentemente de em seus conteúdos tais cartas constitucionais apresentarem uma índole voltada mais ao direito a ações negativas, ou direitos de defesa (ALEXY, 2015, P. 435).

Não é este o caso do Brasil quando visto sob o contexto da promulgação da Constituição Federal de 1988. De fato, com o objetivo de pautar a realidade plural da sociedade brasileira, outrora recém-saída de uma ditadura militar na qual por 20 anos operou-se uma política de restrições de direitos, o Poder Constituinte Originário de 1988, com o escopo de definir a identidade políticonormativa democrática do país, foi pródigo em demarcar, ao lado dos direitos de defesa, um extenso conjunto de direitos a ações positivas do Estado, elencadas em prol de seus cidadãos.

Pois bem, retornando à fundamentação teórica e normativa do direito social à moradia, como um direito a algo, de ação também positiva, importa aqui compreender que, para Robert Alexy, o direito a prestações positivas, situando-se no campo teórico-analítico oposto ao direito de defesa ou de abstenção estatal, é "todo direito a uma ação positiva, ou seja, uma ação do Estado, é um direito a uma prestação". (ALEXY, 2015, p. 442). 


\subsection{Liberdade: direito ao desembaraço a um mínimo existencial}

Pelo que já se compreendeu acerca das noções de impedimento e de dificultação quanto à prestação de uma ação positiva por parte do destinatário de um direito, ou mesmo à não eliminação de posições jurídicas relevantes à sua realização plena, Alexy sugere que a linha tênue que separa a distinção prática de um e de outro pode ser pensada, como dito, desde o supraconceito que defina situações híbridas de impedimento e dificultação como aquelas que podem ser nominadas de embaraços (ALEXY, 2015, p. 197).

Dentro de um sistema de posições jurídicas fundamentais, a liberdade de exercer, em nome da dignidade da existência humana, um direito a algo é, segundo Alexy, constituída por uma relação triádica entre um titular de uma liberdade (ou de uma não-liberdade), um obstáculo à liberdade (um embaraço) e um objeto da liberdade (um direito) (ALEXY, 2015, p. 220).

$\mathrm{O}$ direito à moradia como um direito social constitucionalmente previsto, visto como uma postulação de seu titular em relação ao destinatário, no caso aqui o Estado, quando é pensado em termos da posição jurídica fundamental que ocupa, esta consistente na liberdade de exercê-lo, manifesta-se em termos de liberdade fática e jurídica, cujo objeto é a alternativa de uma ação (ALEXY, 2015, p. 222) sobre a qual não se pode pensar em vedações sem que com isto se fira direitos fundamentais.

[...] liberdade jurídica, isto é, a permissão de se fazer ou deixar de fazer algo, não tem valor sem uma liberdade fática (real), isto é, a liberdade fática de escolher entre as alternativas permitidas. A formulação dessa tese é bastante geral. Mas ela é ao menos necessariamente correta se interpretada de forma a que liberdade jurídica de $a$ de realizar, ou não, a ação $h$ não deixa de ter valor - no sentido de ser inútil - para $a$ se $a$, por razões fáticas, não tem a possibilidade de escolher entre a realização e a não-realização de $h$. (ALEXY, 2015, p. 503)

No caso do direito à moradia, o objeto da liberdade é a alternativa da ação de ocupar o ou não o espaço, segundo os obstáculos impostos a esta ação, de um lado, pelo direito à propriedade privada (não-liberdade jurídica) e, de outro, pela falta de condições financeiras para fazê-lo (nãoliberdade econômica). Todavia, sendo uma liberdade protegida por meio de uma garantia constitucional existente em relação ao Estado, qual seja aquela presente no artigo $6 .^{\circ}$ da Constituição Federal, o direito à moradia constitui-se verdadeira proteção, "um direito de não ser embaraçado no gozo dessa liberdade" (ALEXY, 2015, p. 229), pelo que, sendo um direito à algo - sujeito ao direito a ações negativas e a ações positivas por parte do Estado -, assume no sistema de posições jurídicas fundamentais, a condição de liberdade protegida. 
[...] se trata de tornar faticamente possível ao portador da liberdade aquilo que a ele é permitido e, nesse sentido, juridicamente possível, então existe uma coincidência estrutural. Essa coincidência estrutural justifica, a despeito do uso ordinário da linguagem, chamar de proteção da liberdade também a ligação entre uma liberdade e um direito a uma prestação em sentido estrito, a qual torna possível o real gozo daquilo que é facultativo. (ALEXY, 2015, p. 234)

Portanto, falar em argumento da liberdade, enquanto descritor de uma posição jurídica fundamental que qualifique o direito à moradia como um direito fundamental completo, é pensá-la enquanto elemento que atua preponderantemente em favor do mínimo existencial. Para Sarmento (2016), pensar a liberdade - aqui em termos de uma liberdade não só jurídica, mas também fática, possibilitada prioritariamente por uma atividade estatal - como aquela que guarnece o mínimo existencial seria um argumento persuasivo, uma vez que "o acesso a condições materiais básicas é realmente indispensável para capacitar as pessoas ao exercício das suas liberdades (SARMENTO, 2016, p. 1652).

Para Alexy, o direito ao mínimo existencial tem verdadeiro caráter de regra (ALEXY, 2015b, p. 176) facilitadora de um eficiente juízo de ponderação entre a dignidade da pessoa humana e o da regra de competência restrita à possibilidade financeira do Estado.

A dignidade humana tem prevalência sobre as possibilidades financeiras quando o mínimo existencial não se vê garantido. Sob essa condição o estado é obrigado a assegurar o mínimo existencial; o indivíduo tem um direito indiscutível a isso, e o tribunal constitucional se vê definitiva obrigado a condenar o estado se não cumprir esse dever estatal. (ALEXY, 2015b, p. 177)

Portanto, acerca do que consiste o modelo explicitado na citada Teoria dos Direitos Fundamentais de Robert Alexy, chega-se à definição conceitual de que o direito social à moradia pode ser considerado um "direito fundamental completo", este que em si concentra "um feixe de posições de direitos fundamentais" (ALEXY, 2015, p. 249), que consiste na conjugação da titularidade a um direito a algo, indissociável da liberdade para exercê-lo, na medida em que, em relação ao mesmo, o Estado não crie embaraços para a sua concretização e, ainda, que proteja o seu exercício.

Um direito fundamental completo desse tipo é algo fundamentalmente diverso do direito fundamental completo que é constituído somente por uma conjunção de posições definitivas. Este tem um caráter estático; aquele um caráter dinâmico. Um é o resultado provisório de um processo decisório e argumentativo, que se localiza fora do direito fundamental; o outro inclui exigências que extrapolam esse resultado e, por isso, colide com outros direitos fundamentais e com princípios que dizem respeito a interesses coletivos e, dessa forma, está necessariamente ligado com seu ambiente normativo." (ALEXY, 2014, p. 253)

Chega-se então a um modelo teórico de direito à moradia como direito fundamental completo, tomando como referência a teoria estrutural dos direitos fundamentais de Robert Alexy 
(2015), sem que entretanto se possa simplificar a materialização deste direito social, assim descredenciando-o das possibilidades e limitações financeiras que recaem sobre sua materialização. Para Alexy (2015, p. 176), tal verificação nos encaminha a uma discussão ainda maior acerca da ponderação dos direitos sociais.

\title{
5. O DIREITO À MORADIA É UM DIREITO DIFÍCIL?
}

Para Silva e Masson (2015), os direitos sociais são aqueles endereçados aos indivíduos para os postularem não só contra o Estado, mas contra a sociedade como um todo, sobremaneira quando positivados em lei, o que, segundo os autores, convergem para a conveniência de exigi-los juridicamente. Para Appio (2010), a busca por definir uma postura de equilíbrio da atuação judicial, no que tange à intervenção judicial na consecução de políticas públicas, a hipertrofia do Judiciário é tão democraticamente indesejável quanto a sua indolência.

Ainda que assim o seja, a reserva do possível tem sido a saída utilizada para equacionar aquilo que o indivíduo pode realmente exigir da sociedade e o que está acima da capacidade orçamentária deste ente, o que, muito embora, todavia, não impede o Judiciário de zelar pela efetivação dos direitos sociais, mesmo diante de situações fáticas que exigem difíceis exercícios de ponderação acerca dos custos dos direitos sociais.

\begin{abstract}
A dignidade humana tem precedência sobre possibilidades financeiras quando o mínimo existencial não se vê garantido. Sob essa condição, o Estado é peremptoriamente obrigado a assegurar o mínimo existencial; o indivíduo tem um direito indiscutível a isso, e o tribunal constitucional se vê definitivamente obrigado a condenar o Estado se não cumprir este dever estatal. (ALEXY; SILVA, 2015b, p. 177).
\end{abstract}

O que se coloca aqui em zona limítrofe são dois campos heterogêneos quais sejam o da política e o do direito que, no limite entre o conservadorismo e o intervencionismo, podem se adequar a um modelo de combinação (ALEXY, 2015b, p. 175), que justificaria intervenções proporcionais capazes de estabelecerem judicialmente a concretude democrática de direitos fundamentais prioritários, sobretudo levando-se em conta uma conjuntura social na qual direitos sociais positivamente consignados e intimamente relacionados às necessidades fundamentais das pessoas acham-se muito aquém de serem concretizados.

Lênio Streck (2014) compreende aí um inegável "deslocamento do polo de tensão dos demais poderes em relação ao Judiciário" (STRECK, 2014, p. 198), visto que constrange este último a um certo grau de intervencionismo em prol da redução de desigualdades, intervencionismo este que se acha guarnecido, no caso do direito à moradia, pelo lastro dos princípios constitucionais da função social da propriedade e da cidade, da ponderação de interesses e da proporcionalidade, e 
que se justifica precipuamente em se definir o papel da Constituição Federal em nossa sociedade, assegurando sua força normativa.

Deste modo, reconhece-se que o direito à moradia, como um direito social, intimamente relacionado com o princípio da dignidade da pessoa humana, está situado dentre as normas de direitos fundamentais cuja obrigatoriedade Alexy vai definir a partir de três critérios: normas que garantem direitos subjetivos ou normas que obriguem o Estado de forma objetiva; normas vinculantes ou normas não-vinculantes e, por fim, normas que fundamentem direitos e deveres definitivos, ou prima facie (ALEXY, 2015).

A diversidade acima esboçada dá ensejo à suposição de que o problema dos direitos fundamentais sociais não pode ser resumido a uma questão de tudo ou nada. Parece inevitável que diferenciações sejam feitas. A partir desse pano de fundo, é necessário uma breve análise dos argumentos favoráveis e contrários aos "direitos fundamentais sociais" [...] O objetivo é o desenvolvimento de uma proposta, baseada na teoria dos princípios e na ideia de caráter formal apresentada anteriormente, que leve em consideração tanto os argumentos favoráveis quanto os contrários. (ALEXY, 2015, p. 502-503)

Assim, para o autor, garantir ou não garantir um direito fundamental social é, a priori, uma questão de sopesamento de princípios, este levado a cabo não só a partir da dogmática própria de cada direito fundamental social, o que torna possível a exigência de uma perspectiva infraconstitucional (ALEXY, 2015), mas também considerando o feixe de posições jurídicas que reivindicam sua fundamentalidade de direitos a prestação em sentido estrito a um mínimo existencial.

Portanto considerando o feixe de posições jurídicas fundamentais que qualificam o direito social à moradia não só como um direito a algo, mas além disto, devido à sua estreita ligação com o direito a um mínimo existencial, calçado no princípio da dignidade humana, sendo também um direito relacionado à liberdade de exercê-lo, liberdade não somente jurídica, porque consignada no artigo $6^{\circ}$ da Constituição Federal, mas também fática, uma vez que dependente de uma atividade estatal positiva e prestacional, tem-se que sua concretização judicial não pode deixar de ser apreciada segundo um exercício de ponderação que passe ao largo dessa analítica.

Para além dessa analítica sugerida por Alexy, pesa sob o juízo de ponderação a ser judicialmente exercido, quando em confronto o mínimo existencial e a reserva do possível, o fato de que, sendo um direito inscrito no texto constitucional, nele consignado como um ideal político, não pode o direito à moradia se submeter a estratégias políticas de preferências orçamentárias segundo as quais se opera a supressão e o contingenciamento dos gastos públicos a comprometer preponderantemente os ideias igualmente constitucionais de erradicação da pobreza e da marginalização e na redução das desigualdades sociais e regionais. 
Segundo estudos feitos pela OXFAM Brasil, pelo CERS e pelo INESC (Instituto de Estudos Socioeconômicos) ${ }^{21}$, a imposição de um "Novo Regime Fiscal” no Brasil, conhecido como Emenda do Teto de Gastos ${ }^{22}$, aprovada, convertida e promulgada em 15 de dezembro de 2016 pelo Senado Federal apresentaria forte vocação para exacerbar os níveis de pobreza do país, isto porque, uma vez constitucionalizadas as práticas de austeridade já adotadas nos últimos anos, provocou-se o aumento ainda maior da disparidade orçamentária já verificada desde 2014 entre os gastos sociais e a rolagem da dívida externa. No caso da promoção da moradia digna, por exemplo, o relatório ora citado evidencia que, entre 2014 e 2017, há uma diferença de menos $60 \%$ nestes investimentos, em detrimento de um aumento de mais de $50 \%$ em pagamento de juros e amortizações e mais $334 \%$ em refinanciamento da dívida (OXFAM-BRASIL, 2017, p. 04).

$\mathrm{O}$ aumento das despesas financeiras e a diminuição das despesas primárias ${ }^{23}$, especialmente as discricionárias, impactaram diretamente no cenário das políticas de habitação voltada para os setores de baixa renda. No extinto Programa Minha Casa Minha Vida (faixas 1 e Entidades), já em 2016, a estratégia de gasto público foi a de desaceleração de investimentos, que passaram a priorizar a contratação de unidades para faixas 1,5, 2 e 3, estas com garantia maior

\footnotetext{
${ }^{21}$ Em maio de 2019, entidades como Fórum Nacional de Reforma Urbana (FNRU), Observatório das Metrópoles, Pólis - Instituto de Estudos, Formação e Assessoria em Políticas Sociais, Confederação Nacional das Associações de Moradores (CONAM), Movimento dos Trabalhadores Sem Terra (MST), Movimento Nacional de Luta pela Moradia (MNLM), União dos Movimentos de Moradia da Grande São Paulo, Conselho Nacional de Direitos Humanos, Plataforma de Direitos Humanos (DHESCA-Brasil), Oxfam Brasil, Instituto de Estudos Socioeconômicos (INESC), Coalizão Negra por Direitos, Articulação de Mulheres Brasileiras, dentre outras, ingressaram nas ADIs interpostas contra a Emenda na condição de amici curiae, ocasião em que nelas apresentaram demonstrativos dos efeitos da Emenda do Teto de Gastos na área do acesso ao Direito à Cidade (INESC, 2020b). No documento apresentado à Relatora Ministra Rosa Weber, firmaram a necessidade de concessão de liminar com imposição de suspensão imediata dos efeitos de parte da Emenda Constitucional $n^{\circ}$ 95/2016, para que o "novo regime fiscal" por ela imposto não fosse aplicado à área de saúde pública em razão da pandemia da COVID-19. Neste ponto demonstraram a preocupação da diluição das políticas urbanas constituídas ao longo das últimas quatro décadas, cujo ponto culminante foi a extinção do Ministérios das Cidades em 2018. Nos dados do documento apresentado ao STF, a diminuição dos recursos destinados a essa pasta, que em 2016 já era de 70\% (INESC, 2020b, p. 67), serviu de referência para a incidência dos ajustes aplicados por conta da Emenda, o que teria comprometido a execução de recursos orçamentários aplicáveis à programas de mobilidade, porquanto produzindo consequências como periferização, segregação espacial e diminuição da qualidade de vida urbana.

${ }^{22}$ Em razão desta mudança estrutural no contexto dos gastos públicos, instituída pela Emenda Constitucional n ${ }^{\circ}$ 95, Ações Diretas de Inconstitucionalidade (ADIs nos 5658 , requerente o Partido Democrático Trabalhista; $\mathrm{n}^{\circ} 5680$, requerente o Partido Socialismo e Liberdade; e n ${ }^{\mathrm{a}} 5715$, requerente o Partido dos Trabalhadores) foram interpostas junto ao Supremo Tribunal Federal, sob a relatoria da Ministra Rosa Weber, nas quais apontadas a inconstitucionalidade material da referida alteração normativa. Naquelas ações os demandantes alegaram em face da nova norma o fato de que ela teria sido formulada em discrepância do impedimento pétreo de, por emenda, se abolir garantias constitucionais como saúde e educação, e ainda impor, em detrimento destas mesmas garantias pétreas, severos retrocessos sociais naquelas áreas, cuja responsabilidade de zelo se acharia pactuada pelo país também em normas internacionais.

${ }^{23}$ Segundo dados de pesquisa do INESC, de 2016 para 2017, nas despesas primárias (gastos com investimentos públicos, com pessoal e custeio da máquina pública), operou-se uma redução geral de $14 \%$, enquanto que, no que tange às despesas financeiras (amortização, serviços e remuneração da dívida interna e externa, além de outros gastos de ordem financeira), houve no país um aumento de 46\%, passando assim de $\mathrm{R} \$ 381$ bilhões em 2016 para R $\$ 557$ bilhões em 2017 (INESC, 2017)
} 
retorno em termos de rentabilidade para o mercado, o chamado "dinheiro mais caro" (AMORE, 2015, p.21), que exige retorno e cobra juros.

Segundo dados da Secretaria Nacional de Habitação (BECKER, 2017), os valores de orçamentos executados no Programa, nos de 2015 e 2016, foram, respectivamente, R \$ 16,5 bilhões e R \$ 6,9 bilhões. A visível queda no orçamento para políticas públicas, que já era uma tendência do governo Temer, com a chamada PEC do Teto de Gastos, tornou-se doravante então institucionalizada.

Tal estado de coisas inconstitucional somente resgata a importância e a responsabilidade do Poder Judiciário de manter a sociedade brasileira minimamente vinculada à Constituição Federal, protegendo não só a ameaça de lesão a direitos constitucionalmente positivados, mas também garantindo a eficácia daquelas normas prestacionais a fim de resgatar constantemente a índole e a opção da Carta Constitucional pelo bem-estar social.

\section{CONSIDERAÇÕES FINAIS}

O que inspira o estudo do direito à moradia na dimensão de sua fundamentalidade é o fato de que o tema da habitação digna e socialmente sustentável passou a fazer parte da agenda urbana do planeta e, por isto, fez-se constar em solenes declarações de alcance mundial (ONUBR, 2015).

A sobrecarga da infraestrutura urbana, longe de ser uma distorção conjuntural, revela-se, a despeito da norma que regulamenta o assunto em espécie, um problema estrutural. E o cenário tende a se agravar quando se reconhece o processo de erradicação do estoque público de habitação para efeito de oportunizar a livre circulação do capital financeiro, prática cristalizada pela concessão de crédito habitacional, impulsionada por programas de subsídios para a aquisição de moradia (a exemplo dos Programas Minha Casa Minha Vida e Casa Verde e Amarela), paralela ao declínio de investimentos estatais no setor de habitação.

Os processos de remoções, despejos e reintegrações de posse que tanto são noticiados em escala global e local sintomatizam esta realidade. Pessoas são removidas de suas habitações já consolidadas, submetidas a intenções oficiais de segurança, embelezamento ou saneamento da cidade, ou mesmo de proteção à propriedade privada de terceiros, nas quais, deslocadas dos territórios onde desenvolvem suas redes socioafetivas de pertencimento comunitário, quando não conseguem prover suas necessidades de moradia pela via do ingresso nos programas de financiamento habitacional, são lançadas numa lista de espera para concessão de aluguel público que nem sempre se realiza a contento.

Critério fundamental da pesquisa empreendida foi o de que, uma vez delineado um modelo analítico do direito fundamental à moradia, tomou-se como ponto de partida de análise o princípio 
da dignidade da pessoa humana, este pensado como um parâmetro de natureza substancial absoluto, pelo qual se estabelece um sistema de preferência entre normas (regras e princípios), apontando para a direta promoção de condições de vida que assegurem um bem-estar mínimo que, à sua vez, referencia posições jurídicas fundamentais que categorizam o direito social à moradia como um direito fundamental completo.

O que se pode concluir é que o direito à moradia não pode ser analisado sem levar em conta sua natureza humanitária, coletiva, libertária e prestacional, tampouco as contradições que gravitam em torno do debate sobre a questão de sua imposição judicial não podem se furtar da premissa básica de que se trata de um direito à prestação em sentido estrito, ou seja, que pode ser oposto por seu titular em face do Estado quando não possui recursos para obtê-lo de terceiros ou mesmo do mercado.

Deve-se sempre considerar, em nome do Estado Democrático de Direto que harmoniza toda a lógica constitucional, que a atividade do juiz estará sempre balizada pela Constituição Federal e, ademais, tendo sido uma vez definida a natureza dos direitos sociais como fundamentais, conforme vincula a prescrição do $\S 1 .^{\circ}$ do artigo 5..$^{\circ}$ da Constituição Federal, o Poder Judiciário não pode, sob o esconderijo da reserva do possível e escudado pela vedação da invasão de competências, se furtar de buscar informações práticas de cunho técnico acerca da opção política adotada pelos outros poderes, capazes de criarem embaraços à sua efetiva materialização, para com este fito, exercendo o mais que necessário juízo de ponderação, dar fluxo à realização prática do que inegavelmente é um direito.

\section{REFERÊNCIAS BIBLIOGRÁFICAS}

ALEXY, Robert. Teoria dos Direitos Fundamentais. São Paulo: Malheiros, 2015.

ALEXY Robert; SILVA, Rogério Luiz Nery da. Direitos fundamentais sociais e proporcionalidade, p. 165-178. In: ALEXY, Robert; BAEZ, Narciso Leandro Xavier; SILVA, Rogério Luiz Nery da. (coords.). Dignidade Humana, Direitos Sociais e Não-Positivismo Inclusivo. Florianópolis: Qualis, $2015 b$.

AMORE, Caio Santo. Minha casa... e a cidade? avaliação do Programa Minha Casa Minha Vida em seis estados brasileiros. AMORE, Caio Santo; SHIMBO, Lúcia Zanim; RUFINO, Maria Beatriz Cruz (orgs). 1. ed. Rio de Janeiro: Letra Capital, 2015.

APPIO, Eduardo. O controle judicial de políticas públicas no Brasil. 4a reimp. Curitiba: Juruá, 2010

ARANTES, Pedro Fiori. Em busca do urbano: marxistas e a cidade de São Paulo nos anos de 1970. Novos estudos CEBRAP, n. 83, p. 103-127, 2009. Disponível em: https://www.scielo.br/scielo.php?pid=S0101-33002009000100007\&script=sci_arttext. Acesso em: 18.jul.2020. 
BARROSO, Roberto. O Direito Constitucional e a Efetividade de suas Normas. Rio de Janeiro: Renovar: 2003.

BECKER, Clara. Agência Lupa. 12.mai.2017. O discurso de Michel Temer, um ano depois. Disponível em: http://piaui.folha.uol.com.br/lupa/wp-content/uploads/2017/05/temer-lai-MCMV.pdf. Acesso em: 03.ago.2020.

BOBBIO, Norberto. A Era dos Direitos. Rio de Janeiro: Elsevier, 2004.

BORJA, Jordi. La Ciudad Conquistada. Madrid: Alianza Editorial, 2003.

BRASIL. Constituição (1988). Constituição da República Federativa do Brasil. Brasília: Senado, 2009.

BRASIL. Ministério do Desenvolvimento Regional. Programa Casa Verde e Amarela. Brasília. 28.ago.2020. Disponível em: https://www.gov.br/mdr/pt-br/assuntos/habitacao/casa-verde-e-amarela. Acesso em: 26.jan.2021.

BRASIL. Lei n. ${ }^{\circ}$ 14.118, de 12 de janeiro de 2021. Institui o Programa Casa Verde e Amarela, Brasília, DF, janeiro 2021. Disponível em: http://www.planalto.gov.br/ccivil_03/_Ato20192022/2021/Lei/L14118.htm. Acesso em: 26.jan.2021.

BRASIL. Decreto n. ${ }^{\circ} 10.600$, de 14 de janeiro de 2021. Regulamenta a Lei ${ }^{\circ} 14.118$, de 12 de janeiro de 2021b, que institui o Programa Casa Verde e Amarela, Brasília, DF, janeiro 2021. Disponível em https://www.in.gov.br/en/web/dou/-/decreto-n-10.600-de-14-de-janeiro-de-2021-299074435. Acesso em: 26.jan.2021.

BRASIL. Tribunal de Justiça do Amazonas. Apelação Cível proposta por Carlos Alberto Brito de Lima contra o Município de Manaus, na qual busca, em face do Município de Manuas (AM), a implementação do direito à moradia de famílias residentes em área de risco. Apelação Cível $\mathrm{n}^{\circ}$ 064930986.2019.8.04.0001, Voto n. ${ }^{\circ}$ 537/2020 movida por Carlos Alberto Brito de Lima contra o Município de Manaus. Primeira Câmara Cível do Tribunal de Justiça do Amazonas. 15 de setembro de 2020. Disponível em: https://tj-am.jusbrasil.com.br/jurisprudencia/927463455/apelacao-civel-ac6493098620198040001-am-0649309-8620198040001/inteiro-teor-927463486?ref=juris-tabs. Acesso em: 06.jan.2021.

BRASIL. Tribunal de Justiça do Rio Grande do Sul. Agravo de Instrumento proposto por Município de Sant'Ana do Livramento contra o Ministério Público, Cecilia Alves Martinez e Yuri Alex Alves Mateus, que emerge de ação civil pública na qual busca, em face do Município de Sant'Ana do Livramento (RS), a implementação do direito à moradia de família residente em área de risco. Agravo de instrumento ${ }^{\circ}$ 70081712523 movido por Município de Sant'Ana do Livramento contra o Ministério Público, Cecilia Alves Martinez e Yuri Alex Alves Mateus. Vigésima Primeira Câmara Cível do Tribunal de Justiça do Rio Grande do Sul. 02 de outubro de 2019. Disponível em: https://www.tjrs.jus.br/novo/busca/?return=proc\&client=wp_index\&combo_comarca=700\&comarca= \&numero_processo $=01431619720198217000 \&$ numero_processo_desktop $=01431619720198217000 \&$ $\mathrm{CNJ}=\mathrm{S} \&$ comarca $=\&$ nome_comarca $=\& u f \_\mathrm{OAB}=\& \mathrm{OAB}=\&$ comarca $=\&$ nome_comarca $=\&$ nome_parte =. Acesso em: 06.jan.2021.

BRASIL. Tribunal de Justiça de São Paulo. Apelação Cível em que é apelante o Município de São Paulo e apelada Antonia Helia Soares na qual discute ser a concessão do auxílio aluguel decisão de caráter discricionário, sujeita à disponibilidade orçamentária e financeira do Município. Apelação Cível $\mathrm{n}^{\circ}$ 1037862-04.2015.8.26.0053 movido por Município de São Paulo contra Antonia Helia Soares. 2 ${ }^{\mathrm{a}}$ Câmara de Direito Público do Tribunal de Justiça de São Paulo. 11 de junho de 2020. Disponível em: http://esaj.tjsp.jus.br/cjsg/resultadoCompleta.do?dados.nuProcOrigem $=10378620420158260053 \&$ tipo DecisaoSelecionados=A\&tipoDecisaoSelecionados $=\mathrm{R} \&$ tipoDecisaoSelecionados $=\mathrm{H} \&$ tipoDecisaoSel 
ecionados=D. Acesso em: 06.jan.2021.

CAIXA. Casa Verde e Amarela - Habitação Urbana - Recursos FGTS. Promovendo o direito à moradia. Disponível em: https://www.caixa.gov.br/voce/habitacao/casa-verde-eamarela/urbana/Paginas/default.aspx. Acesso em: 26.jan.2021.

CHINCHILLA HERRERA, Tulio Elí. ¿Qué son y cuáles son los Derechos Fundamentales?”. Bogotá: Editorial Temis, 2009.

COMPANS, Rose. Cidades Sustentáveis, Cidades Globais: antagonismo ou complementaridade? p. 121-154. In: ACSELRAD, Henri. (org.). A Duração das Cidades: Sustentabilidade e risco nas políticas urbanas. Rio de Janeiro: Lamparina, 2009.

CUNHA JÚNIOR, Dirley. Curso de Direito Constitucional. 10ª ed. Salvador: JusPODIVM, 2016, p. 554.

DWORKIN, Ronald. Levando os Direitos a sério. São Paulo: Martins Fontes, 2010.

DWORKIN, Ronald. A Virtude Soberana: a teoria e a prática da igualdade. São Paulo: Martins Fontes, 2013.

ESCRIVÃO FILHO, Antônio; SOUSA JÚNIOR, José Geraldo de. Para um debate teórico-conceitual e político sobre os direitos humanos. Editora D'Plácido, 2016.

FOUCAULT, Michel. História da sexualidade I: a vontade de saber. Rio de Janeiro: Edições Graal, 1999.

FOUCAULT, Michel. Em defesa da sociedade: curso no Collège de France (1975-1976). São Paulo: Martins Fontes, 2005.

FOUCAULT, Michel. Segurança, território e população: curso no Collège de France (1977-1978). São Paulo: Martins Fontes, 2008.

FOUCAULT, Michel. O nascimento da biopolítica: curso no Collège de France (1978-1979). São Paulo: Martins Fontes, 2008b.

FOUCAULT, Michel. A Arqueologia do Saber. Rio de Janeiro: Forense Universitária 2012.

FGV. FGV Projetos: Análise das necessidades habitacionais e suas tendências para os próximos dez anos - ABRAINC. Outubro, 2018. Disponível em: https://www.abrainc.org.br/wpcontent/uploads/2018/10/ANEHAB-Estudo-completo.pdf. Acesso em: 18.ago.2020.

FUNDAÇÃO JOÃO PINHEIRO. Déficit habitacional no Brasil 2015/ Fundação João Pinheiro, Diretoria de Estatística e Informações. - Belo Horizonte : FJP, 2018. 78 p.. Disponível em: http://www.bibliotecadigital.mg.gov.br/consulta/verDocumento.php?iCodigo=76871\&codUsuario $=0$. Acesso em: 17.ago.2020.

IBGE. População em áreas de risco no Brasil / IBGE, Coordenação de Geografia. - Rio de Janeiro: IBGE, 2018. Disponível em: https://biblioteca.ibge.gov.br/index.php/bibliotecacatalogo? view $=$ detalhes $\& i d=2101589$. Acesso em: 22.abr.2020.

INESC. Orçamento 2017 prova: teto dos gastos achata despesas sociais e beneficia sistema financeiro. 14.mar.2017. Disponível em: https://www.inesc.org.br/orcamento-2017-prova-teto-dosgastos-achata-despesas-sociais-e-beneficia-sistema-financeiro-3/. Acesso em 06.08.2020.

MARTINS, Ricardo Marcondes. Estudos de Direito Administrativo Neoconstitucional. São Paulo: 
Malheiros Editores, 2015.

ONU. World Urbanization Prospects 2018. Disponível em: https://population.un.org/wup/ CountryProfiles/. Acesso em 06.out.2020.

ONU. Declaração Universal dos Direitos do Homem. 10 de dezembro de 1948. Disponível em $<$ https://nacoesunidas.org/> Acesso em 29.jul.2016.

OXFAM-BRASIL. Levantamento realizado pelo Inesc, Oxfam Brasil e CESR foi apresentado em audiência pública na Câmara. 14.dez.2017. Disponível em: https://www.oxfam.org.br/noticias/tetode-gastos-estudo-revela-queda-de-ate-83-em-politicas-publicas-para-area-social/. Acesso em 06.08 .2020

SARLET, Ingo Wolfgang. A Eficácia dos Direitos Fundamentais. Porto Alegre: Livraria do Advogado Editora, 2012.

SARLET, Ingo Wolfgang. A dignidade da pessoa humana, p. 533-548. In: CANOTILHO. J. J. Gomes; MENDES, Gilmar Ferreira; SARLET, Ingo Wolfgang; STRECK, Lênio Luiz. (coords.). Comentários à Constituição do Brasil. São Paulo: Saraiva/Almedina, 2014.

SARLET, Ingo Wolfgang. Dignidade da pessoa humana: notas em torno da discussão sobre o seu caráter absoluto ou relativo na ordem jurídico-constitucional, p. 91-121. In: ALEXY, Robert; BAEZ, Narciso Leandro Xavier; SILVA, Rogério Luiz Nery da. (coords.). Dignidade Humana, Direitos Sociais e Não-Positivismo Inclusivo. Florianópolis: Qualis, 2015.

SARMENTO, Daniel. O mínimo existencial. Revista de Direito da Cidade, v. 8, n. 4, p. 1644-1689, 2016. Disponível em: https://www.e-publicacoes.uerj.br/index.php/rdc/article/view/26034. Acesso em: 28.dez.2020.

SAULE JÚNIOR, Nelson. Novas Perspectivas do Direito Urbanístico Brasileiro - Ornamento constitucional da política urbana - Aplicação e eficácia do Plano Diretor. Porto Alegre: Sérgio Antônio Fabris Editor, 1997.

SILVA, Rogério Luiz Nery da; MASSON, Daiane Garcia. Direitos sociais e dignidade da pessoa humana: reflexões a partir do conceito de mínimo existencial, p. 179-214. In: ALEXY, Robert; BAEZ, Narciso Leandro Xavier; SILVA, Rogério Luiz Nery da. (coords.). Dignidade Humana, Direitos Sociais e Não-Positivismo Inclusivo. Florianópolis: Qualis, 2015.

STRECK, Lenio Luiz. Verdade e Consenso. São Paulo: Saraiva, 2014.

TAVARES, André Ramos. Curso de Direito Constitucional. 12ª ed. São Paulo: Saraiva: 2014.

VAINER, Carlos B. Pátria empresa e mercadoria: notas sobre a estratégia discursiva do planejamento estratégico urbano. p. 75-119. In: ARANTES, Otília; VAINER, Carlos; MARICATO, Ermínia (Coords). A cidade do pensamento único: desmanchando consensos. Petrópolis: Vozes, 2013.

Trabalho recebido em 12 de fevereiro de 2021

Aceito em 17 de junho de 2021 